\title{
An overview of CD19 in COVID-19: Insights from Primary Immunodeficiencies and B cell depleting therapies
}

RUNNING TITLE: $B$-cells in COVID-19

\author{
AUTHORS : \\ Pulukool Sandhya', Abhinav Jain ${ }^{2,3}$,Geeta Govindaraj ${ }^{+}$
}

\begin{abstract}
AFFILIATIONS:
' Department of Rheumatology, St Stephen's Hospital, Tis Hazari Delhi 110054, INDIA drsandhya.p123@gmail.com

${ }^{2}$ Genomics and Molecular Medicine, CSIR Institute of Genomics and Integrative Biology (CSIRIGIB), Mathura Road, Delhi 110025, INDIA.abhinav.jain@igib.in

${ }^{3}$ Academy of Scientific and Innovative Research (AcSIR), CSIR-HRDC Campus, Sector 19, Kamla Nehru Nagar, Ghaziabad, Uttar Pradesh 201002, INDIA

${ }^{4}$ Department of Pediatrics, Government Medical College Kozhikode, Kerala 673008 INDIA geetakkumar@gmail.com
\end{abstract}




\section{Corresponding Author}

Pulukool Sandhya

Department of Rheumatology, St Stephen's Hospital, Tis Hazari Delhi 110054, INDIA

drsandhya.p123@gmail.com

\section{AUTHOR CONTRIBUTIONS}

Reports for Autoimmune Diseases and COVID-19 were collected by PS. Reports for primary immunodeficiency diseases were collected by AJ and GG. All the authors contributed to the writing of the manuscript.

\section{ACKNOWLEDGEMENTS}

Authors acknowledge Vinod Scaria for critical comments and assistance in preparation of the manuscript. Authors acknowledge Yoni Maisel for painstakingly collecting and sharing evidence on COVID-19 and primary immunodeficiency diseases on Twitter handle @Primary_Immune.

\section{CONFLICT OF INTEREST STATEMENT}

Authors declare no conflicts of interest. 


\section{ABSTRACT}

The evolution of COVID-19 as a global pandemic and emerging evidence from cohorts of patients have provided an immense opportunity to understand biological processes pertinent to development of the disease. The immune system is central to the development of characteristic hyperinflammation. In an attempt to understand the role of humoral immunity in COVID-19, reports encompassing patients with primary immunodeficiency (PID)(13 patients) and on B cell depletion therapies(39 patients) who had concurrent COVID-19 were reviewed. In PIDs, patients with common variable immunodeficiency had worse outcomes than patients with agammaglobulinemia. Among the patients on B cell depletion therapy, heterogenous outcome was seen. As a group, patients with multiple sclerosis had better outcomes as compared to patients with systemic autoimmunity. Further, increasing reports of autoimmunity and autoinflammatory diseases occurring in temporal relation to COVID-19 is also evidence for the pathogenic role played by B cells. B cell depletion in the setting of COVID-19 may not be harmful in all patients and in fact may be protective in some scenarios. Identification of risk factors associated with a worse outcome in patients on B cell therapy could provide a rationale for individualised management.

KEYWORDS: COVID-19, B-cell, Primary Immunodeficiency, rituximab, anti-CD20 therapy, autoimmunity, rheumatic diseases 


\section{Introduction}

The COVID-19 pandemic has resulted in an unprecedented crisis necessitating a deeper understanding of disease biology. The disease in a minority of patients is severe and characterized by the development of respiratory distress, heralded by elevated cytokines, and influx of neutrophils and macrophages, resulting in widespread inflammation. Older age and presence of comorbidities such as cardiovascular disease, chronic kidney disease, hypertension, diabetes mellitus, and malignancy have been identified as risk factors portending worse outcomes [1]. Conventionally, immunosuppressed patients are considered to be at high risk in case of infectious outbreaks and therefore initially, were also considered as a risk group for severe COVID-19. However, the plethora of literature that has emerged during the pandemic has given new insights, and many of them seem to challenge conventional wisdom. Drugs that suppress the immune system have been used successfully in the treatment of COVID-19 such as dexamethasone[2] .

The major sources of evidence on the role of immune deficiency in modulating disease pathophysiology in COVID-19 is gained from studying patients suffering from primary immunodeficiencies(PID), as well as patients on immunosuppressive medications. PIDs are rare entities resulting from mutations in key genes involved in the development, maturation and function of the immune system. Nevertheless, as they form naturally occurring gene knockouts, they provide a unique opportunity to study gene function and response to the environment including infections. Apart from this, pharmacological suppression of the immune components is widely used to treat several autoimmune diseases spanning specialities of rheumatology, 
oncology and neurology. This has resulted in a unique pool of patients who could potentially improve our understanding of the effect of immunosuppression in pathogenesis of COVID-19.

In this commentary, we sought to re-examine the available literature assessing the outcome of patients suffering from PIDs as well as those receiving ongoing or prior B-cell targeted therapies and concurrent COVID-19 as diagnosed by Reverse Transcription-Polymerase Chain Reaction (RT-PCR) or Computed Tomography (CT) of the lung. As of 1st August 2020, data on 13 patients with primary immunodeficiency and 39 patients on B cell depletion therapies are summarised in Table 1 and Table 2, respectively and are discussed in the initial half of the paper. In the light of these cases, we hypothesise the relevance of B cells in COVID-19 in the latter part of the paper.

\section{Lessons from PID: No B cells better than dysfunctional B cells?}

In PIDs, we could retrieve 6 case reports describing a total of 13 patients ( 9 males) with a median age of 41(8-59) years who had concurrent COVID-19. Patients with autosomal recessive agammaglobulinemia(ARA)(P4) and X-linked agammaglobulinemia (XLA)(P1,P2,P3) had milder disease as compared to those with common variable immunodeficiency (CVID)[3, 4]. This suggests that recovery from COVID-19 is possible without B cell help. Additionally, the Bruton tyrosine kinase (BTK) enzyme deficient in XLA is also required for the activation of macrophages, and IL-6 production in COVID-19, as suggested by the success of acalabrutinib in treating hyperinflammation in COVID-19[5]. A child with specific antibody deficiency (SAD)(P13) also had a mild disease[6]. Further, among those with CVID, lower CD19 was associated with better outcome [3]. The only patient who died (P5) in the PID group had the highest CD19 levels and the highest IgA levels amongst all. The three patients with the highest 
CD19 (P5, P6, P9) were also the ones who received tocilizumab[3]. Two other single case reports (P10, P11) described severe disease in patients with CVID requiring ventilation [7, 8]. This could imply that immune dysregulation including dysfunctional B cells contributes to the severe inflammatory phenotype in CVID. This is exemplified by P12 with autoimmune lymphoproliferative syndrome (ALPS) in whom COVID-19 triggered production of new onset autoantibodies against red blood cells resulting in severe hemolytic anemia that responded to intravenous glucocorticoids[9].

\section{Lessons from anti-CD20 therapy: Cautious use in systemic autoimmunity}

This group included patients with autoimmune diseases (rheumatological, neurological, hematological, dermatological) and hematological malignancies. Both case series as well as single case reports have been included.

\section{Rheumatological diseases}

This group includes three cases with anti-neutrophil cytoplasmic antibodies (ANCA)-associated vasculitis (AAV)-granulomatous polyangiitis (GPA)[10-12], four cases each with scleroderma $(\mathrm{SSc})[13,14]$ and rheumatoid arthritis $(\mathrm{RA})[15,16]$ and one patient with systemic lupus erythematosus (SLE)[18]. Median age of the group was 54 (27-84) years.

All three patients with GPA (P14,P15,P16) had received rituximab in the preceding 1 month. A 52 year old lady who had received rituximab a day before onset of COVID-19 developed delayed worsening necessitating mechanical ventilation[10]. However, she recovered despite long-standing AAV and additional comorbidities (hypertension and overweight). A 27 year old lady with recent diagnosis of GPA had a favourable outcome after treatment with supplemental 
oxygen and tocilizumab[11]. However, most intriguing was the case of P16, a 77 year old lady who had a mild illness and cleared the virus even in the absence of anti-SARS-CoV-2 IgGs[12] .

Avouac et al. reported three patients (P17, P18, P19) with scleroderma who had severe COVID19[13]. Though all of them recovered, delayed clinical worsening was observed. However, it is noteworthy that P17 and P18 recovered despite the presence of adverse prognostic factors (higher age in both, hypertension in the first patient and chronic kidney disease and pulmonary embolism in the second patient). Patient 18 received tocilizumab. Mortality was reported by Favalli et al in P20, a 32 year old lady with scleroderma and lung involvement. She was ventilated and treated with tocilizumab but unfortunately did not survive [14].

Of the four patients with RA, P21 and P22 had favourable outcomes [15]. P21, a 54 year old lady required supplemental oxygen, but improved with tocilizumab despite multiple comorbidities[16]. Patients P23 and P24 died. Risk factors included age and presence of comorbidities[17]. Hospital course of P23, a 71 year old male was complicated by shock and renal failure.

Gartshteyn et al.[18] reported a case series of lupus patients with COVID-19. There was only one confirmed COVID-19 patient, P25 who was on rituximab. P25 had mild symptoms, necessitating only outpatient treatment and subsequently recovered.

Apart from the twelve patients described above, Fredi et al. reported four patients (P26-P29) who were on concurrent or previous rituximab in a series of 65 confirmed COVID-19 patients[19]. All four patients required hospitalisation but recovered. Data regarding comorbidities, lab parameters and need for ICU stay/ventilation were not available. 


\section{Dermatological Diseases}

P30, a 43 year old man with mucous membrane pemphigoid received intravenous immunoglobulin (IVIG) and also recovered despite multiple comorbidities[20].

\section{Neurological Diseases}

This group consisted of 10 patients (P31-P40) with multiple sclerosis (MS)[21-24] and 1 patient, P41 with neuromyelitis optica with a median age of 49 (25-60) years[25]. No mortality was reported in any of these patients. Most had no comorbidities and had mild disease or were asymptomatic. Patients were treated with rituximab/ocrelizumab and most patients had total depletion of CD19 levels documented within the preceding 3 months. Despite this, 3 out of 4 patients in whom the serological assay was done tested positive for anti-SARS-CoV-2 IgG/IgM[21]. Creed et al. described P41, a 59-year-old lady with anti-aquaporin-4-positive neuromyelitis optica[25] who also had a mild COVID-19 disease. However, diagnosis of COVID-19 was preceded by one month of intermittent flu-like illness though it is unclear if this was an atypical presentation of COVID-19[25].

\section{Hematological malignancies}

While cancer patients were initially considered to be at high risk for COVID-19 based on initial reports, subsequent studies suggest that mortality may not be related to the malignancy or ongoing anti-cancer therapy. He et al.[26] reported the outcome in 128 hospitalised patients with hematological malignancies. All patients were screened for COVID-19 by CT of lung and if positive, further confirmed by RT-PCR. Thirteen out of 128 patients had COVID-19, out of which five died. However, none of the 18 patients with non-Hodgkin's lymphoma (NHL) had 
COVID-19. As CT was the first step and RT-PCR was not done at all, it is possible that at least some of these patients had mild disease. Demography, comorbidities treatment details of these NHL patients or their lymphocyte subsets are not mentioned, though it can be assumed that NHL patients were treated with rituximab -based intensive chemotherapy regimen [26]. Aries et al.[27] described clinical outcomes in 35 patients with hematological malignancy of which eight patients(P42-P49) underwent rituximab-based chemotherapy regimen. With the exception of two patients ( $\mathrm{P} 42$ and $\mathrm{P} 46)$, all were receiving rituximab at the time of COVID-19 testing and contrary to expectation, the only patient who died (P42) was the one not on ongoing rituximab at the time of COVID-19. P50, a 26 year old male with mediastinal large B cell lymphoma had a mild disease, despite being on intensive chemotherapy with DAEPOCH-R (dose-adjusted etoposide, prednisone, vincristine, cyclophosphamide, doxorubicin, and rituximab)[28]. In another study, Tepasse et al. has reported mortality in 2 male patients (P51, P52) in their 60s [29]. P51 had diffuse large B cell lymphoma whereas P52 had mantle cell lymphoma. Both the patients developed cytokine storm, delayed respiratory failure and died. Both patients also had high procalcitonin levels. Persisting SARS-Cov-2 viremia in these patients indicates lack of viral clearance [29].

Put together, emerging data shows that in most patients, B-cell depletion may not always be detrimental. A dichotomy in response is noted in patients with neurological disease as compared to rheumatological illness and PID. Recent study on MS patients from the French registry reinforces the observation that disease modifying therapies including B cell depletion are not associated with severe COVID-19[30]. Of 347 patients, 55 were on B-cell depletion therapy (rituximab-17, ocrelizumab-38). Disability, age and obesity were independently associated with worse outcomes [30]. Notably, severe COVID-19 was more frequent in those not on disease 
modifying therapy as compared to those on treatment. Of the 12 patients who died, only one was on anti-CD20 therapy (rituximab) and this patient had discontinued rituximab 18 months prior to onset of COVID-19. Three patients on anti-CD20 therapy required ventilation [30].

In contrast, in rheumatological diseases and PIDs, multiple patients had a prolonged course of illness requiring ventilation. In this group, two patients with RA and one patient each with systemic sclerosis (SSc) and CVID died [3, 14, 17]. Fredi et al. has recently reported that the adverse outcome in patients with rheumatic diseases was related to age and other comorbidities rather than the underlying diagnosis or immunosuppression[19]. While mortality in RA patients is consistent with the study by Fredi et al., worse outcomes in other patients in the rheumatology group and death of P5 with CVID cannot be explained by age, comorbidities or degree of immunosuppression alone. For instance, as a group, AAV patients had a more immunosuppressive regimen than those with SSc and had received rituximab closer to the diagnosis of COVID-19[10-12]. Whether severe COVID-19 disease is related to the more widespread immunological aberrations associated with systemic autoimmune disease/CVID or the predominant organ affected being the lung in these two conditions needs to be investigated upon. Considering the heterogeneous outcome and potential for severe disease, it is prudent to be cautious in the use of rituximab in these patients until data from large registries are available. It is difficult to compare the lymphoma group with the other patient groups, in the absence of data related to CD19 levels, details of comorbidities and course of disease including ventilatory requirement and treatment received. Nevertheless, it is surprising to note that patients with lymphoma survived despite being on intense immunosuppression with rituximab, cyclophosphamide, hydroxydaunomycin, oncovin and prednisone (R-CHOP) at the time of diagnosis [27]. 
Humoral immunity is believed to generate neutralising antibodies that help in resolution of infection and B cell depletion is a known risk factor for infection. In this background, how could one account for the mild disease seen in some patients on anti-CD20 therapy? There is increasing evidence that $\mathrm{T}$ cells and innate responses are major determinants of outcome in COVID-19[3135]. Viral clearance may be possible in the absence of a robust humoral response [35]. For instance, P16, the 77 year old lady with AAV recovered in the absence of antibodies [11]. Lack of consistent response to convalescent plasma therapy also seems to question the role of B cells in recovery from COVID-19[36, 37] .Furthermore, even in the general population, only low titers of neutralising antibodies have been identified in those who recovered from COVID19[38]. In this context, the presence of anti-SARS-Cov-2 antibody in some B cell depleted patients, though surprising, could be explained by the ability of anti-CD20 refractory tissue resident memory B cells to generate antibody responses[39]. If COVID-19 infection would produce long lasting immunity even in immunocompetent individuals is not known. However, it is indeed a matter of concern if those on B cell depleting therapy would be able to generate robust immunological memory in response to infection or vaccination (when it becomes available)[40].

The next question to be addressed is the biological plausibility of the beneficial effect of B cell depletion. This apparent paradox could potentially be explained by the following observations. Firstly, all antibodies generated against SARS-CoV-2 may not be protective. In fact, antibodies bound to activating Fc-receptor could result in a proinflammatory response and can be detrimental. This process is termed as antibody-dependent enhancement [41]. High titers of antiSARS-CoV-2-specific antibodies found in those with severe disease could partly support this 
theory [42]. Further, anti-spike IgGs in SARS-CoV/macaque models have been found to drive lung inflammation by recruiting and activating macrophages [43]. Secondly, unlike the typical cytokine release syndromes where the innate immune system is implicated, COVID-19 seems to have more of a subacute presentation and worsening is seen generally after one week of disease onset. The fact that this is also the time when humoral immunity comes into play could suggest a role for B cells in the dysregulated immune response [44]. B cell derived cytokines could also have an important role in the pathogenic inflammatory response. Thirdly, it has been found that Th2 cytokines increase with the severity of disease in COVID-19[45]. In this context, it is relevant to recall the close interactions between Th2 cytokines and B cells. Activated B cells can promote a selective Th2 response by modulating dendritic cells [46]. Finally, the occurrence of autoimmune and autoinflammatory diseases in temporal relation to COVID-19 is testament to the development of pathogenic autoantibodies and immune activation [47]. Immune thrombocytopenia, autoimmune hemolytic anemia, antiphospholipid antibodies and coagulopathy, Guillain-Barré syndrome and Kawasaki-like multisystem inflammatory disease have been described following COVID-19[47]. This is not unexpected as viral infection is known to trigger autoimmunity by mechanisms of molecular mimicry or bystander activation[48]. In one such instance of autoimmune hemolytic anemia following COVID-19, a 61 year old male patient was treated with rituximab following inadequate response to steroids [49].

In conclusion, the present observations suggest that B cells have a complex role in modulating the pathophysiology of COVID-19. Heterogenous outcome in systemic autoimmune diseases could result from complex interactions of the numerous risk factors. Immune dysregulation of the primary disease, therapeutic immunosuppression by rituximab and other drugs, age and other 
comorbidities could all have a role in determining outcome in COVID-19. Identification of risk factors associated with a worse outcome in patients on B cell therapy could provide a rationale for individualised management. At the same time, it would be prudent not to defer therapy in patients at a high risk of relapse of their primary disease. Therefore, there is an unmet need for a systematic study to evaluate the effect of B-cell depletion in COVID-19. The other important aspect which has not escaped our attention is the potential for B-cell depletion as a therapeutic option at least in a subset of patients with hyperinflammatory response in COVID-19. As of date, while there are many immunosuppressants in clinical trials for COVID-19, anti-CD20 therapy is not yet one of them.

\section{CONFLICT OF INTEREST STATEMENT}

Authors declare no conflicts of interest.

\section{REFERENCES}

1. Guan W, Liang W, Zhao Y, et al (2020) Comorbidity and its impact on 1590 patients with COVID-19 in China: a nationwide analysis. Eur Respir J 55:. https://doi.org/10.1183/13993003.00547-2020

2. RECOVERY Collaborative Group, Horby P, Lim WS, et al (2020) Dexamethasone in Hospitalized Patients with Covid-19 - Preliminary Report. N Engl J Med. https://doi.org/10.1056/NEJMoa2021436

3. Quinti I, Lougaris V, Milito C, et al (2020) A possible role for B cells in COVID-19? Lesson from patients with agammaglobulinemia. J Allergy Clin Immunol. https://doi.org/10.1016/j.jaci.2020.04.013

4. Soresina A, Moratto D, Chiarini M, et al (2020) Two X-linked agammaglobulinemia patients develop pneumonia as COVID-19 manifestation but recover. Pediatr Allergy Immunol. https://doi.org/10.1111/pai.13263

5. Roschewski M, Lionakis MS, Sharman JP, et al (2020) Inhibition of Bruton tyrosine kinase in patients with severe COVID-19. Sci Immunol 5:. https://doi.org/10.1126/sciimmunol.abd0110

6. Ahanchian H, Moazzen N, Faroughi MSD et al. (2020) COVID-19 in a Child with Primary 
Specific Antibody Deficiency. https://doi.org/10.21203/rs.3.rs-28155/v1

7. Fill L, Hadney L, Graven K, et al (2020) The clinical observation of a patient with common variable immunodeficiency diagnosed as having coronavirus disease 2019. Ann Allergy Asthma Immunol Off Publ Am Coll Allergy Asthma Immunol 125:112-114. https://doi.org/10.1016/j.anai.2020.04.033

8. Aljaberi R, Wishah K (2020) Positive Outcome in a COVID-19 patient with Common Variable Immunodeficiency after IVIG. Ann Allergy Asthma Immunol. https://doi.org/10.1016/j.anai.2020.06.006

9. Wahlster L, Weichert-Leahey N, Trissal M, et al COVID-19 presenting with autoimmune hemolytic anemia in the setting of underlying immune dysregulation. Pediatr Blood Cancer n/a:e28382. https://doi.org/10.1002/pbc.28382

10. Guilpain P, Bihan CL, Foulongne V, et al (2020) Rituximab for granulomatosis with polyangiitis in the pandemic of covid-19: lessons from a case with severe pneumonia. Ann Rheum Dis. https://doi.org/10.1136/annrheumdis-2020-217549

11. Sharmeen S, Elghawy A, Zarlasht F, Yao Q (2020) COVID-19 in rheumatic disease patients on immunosuppressive agents. Semin Arthritis Rheum 50:680-686. https://doi.org/10.1016/j.semarthrit.2020.05.010

12. Fallet B, Kyburz D, Walker UA Mild course of Coronavirus disease 2019 and spontaneous severe acute respiratory syndrome coronavirus 2 clearance in a patient with depleted peripheral blood B-cells due to treatment with rituximab. Arthritis Rheumatol n/a: https://doi.org/10.1002/art.41380

13. Avouac J, Airó P, Carlier N, et al (2020) Severe COVID-19-associated pneumonia in 3 patients with systemic sclerosis treated with rituximab. Ann Rheum Dis. https://doi.org/10.1136/annrheumdis-2020-217864

14. Favalli EG, Agape E, Caporali R (2020) Incidence and clinical course of COVID-19 in patients with connective tissue diseases: a descriptive observational analysis. J Rheumatol. https://doi.org/10.3899/jrheum.200507

15. Haberman R, Axelrad J, Chen A, et al (2020) Covid-19 in Immune-Mediated Inflammatory Diseases - Case Series from New York. N Engl J Med. https://doi.org/10.1056/NEJMc2009567

16. Conticini E, Bargagli E, Bardelli M, et al (2020) COVID-19 pneumonia in a large cohort of patients treated with biological and targeted synthetic antirheumatic drugs. Ann Rheum Dis. https://doi.org/10.1136/annrheumdis-2020-217681

17. Schulze-Koops H, Krueger K, Vallbracht I, et al (2020) Increased risk for severe COVID19 in patients with inflammatory rheumatic diseases treated with rituximab. Ann Rheum Dis. https://doi.org/10.1136/annrheumdis-2020-218075

18. Gartshteyn Y, Askanase AD, Schmidt NM, et al (2020) COVID-19 and systemic lupus erythematosus: a case series. Lancet Rheumatol 2:e452-e454. https://doi.org/10.1016/S2665-9913(20)30161-2

19. Fredi M, Cavazzana I, Moschetti L, et al (2020) COVID-19 in patients with rheumatic 
diseases in northern Italy: a single-centre observational and case-control study. Lancet Rheumatol 0: https://doi.org/10.1016/S2665-9913(20)30169-7

20. M D, T S, A I, P N (2020) Mucous membrane pemphigoid and COVID-19 treated with high-dose intravenous immunoglobulins: a case report. In: J. Dermatol. Treat. https://pubmed.ncbi.nlm.nih.gov/32363963/. Accessed 9 Aug 2020

21. Meca-Lallana V, Aguirre C, Beatrizdel Río null, et al (2020) COVID-19 in 7 multiple sclerosis patients in treatment with ANTI-CD20 therapies. Mult Scler Relat Disord 44:102306. https://doi.org/10.1016/j.msard.2020.102306

22. Montero-Escribano P, Matías-Guiu J, Gómez-Iglesias P, et al (2020) Anti-CD20 and COVID-19 in multiple sclerosis and related disorders: A case series of 60 patients from Madrid, Spain. Mult Scler Relat Disord 42:102185. https://doi.org/10.1016/j.msard.2020.102185

23. Novi G, Mikulska M, Briano F, et al (2020) COVID-19 in a MS patient treated with ocrelizumab: does immunosuppression have a protective role? Mult Scler Relat Disord 42:102120. https://doi.org/10.1016/j.msard.2020.102120

24. Devogelaere J, D'hooghe MB, Vanderhauwaert F, D'haeseleer M (2020) Coronavirus disease 2019: favorable outcome in an immunosuppressed patient with multiple sclerosis. Neurol Sci Off J Ital Neurol Soc Ital Soc Clin Neurophysiol. https://doi.org/10.1007/s10072-020-04522-2

25. Creed MA, Ballesteros E, Jr LJG, Imitola J (2020) Mild COVID-19 infection despite chronic B cell depletion in a patient with aquaporin-4-positive neuromyelitis optica spectrum disorder. Mult Scler Relat Disord 44:102199. https://doi.org/10.1016/j.msard.2020.102199

26. He W, Chen L, Chen L, et al (2020) COVID-19 in persons with haematological cancers. Leukemia 34:1637-1645. https://doi.org/10.1038/s41375-020-0836-7

27. Aries JA, Davies JK, Auer RL, et al (2020) Clinical outcome of coronavirus disease 2019 in haemato-oncology patients. Br J Haematol. https://doi.org/10.1111/bjh.16852

28. Li Q, Zhu F, Xiao Y, et al (2020) A Primary Mediastinal Large B-Cell Lymphoma Patient With COVID-19 Infection After Intensive Immunochemotherapy: A Case Report. Front Oncol 10:924. https://doi.org/10.3389/fonc.2020.00924

29. Tepasse P-R, Hafezi W, Lutz M, et al (2020) Persisting SARS-CoV-2 viraemia after rituximab therapy: two cases with fatal outcome and a review of the literature. $\mathrm{Br} \mathrm{J}$ Haematol. https://doi.org/10.1111/bjh.16896

30. Louapre C, Collongues N, Stankoff B, et al (2020) Clinical Characteristics and Outcomes in Patients With Coronavirus Disease 2019 and Multiple Sclerosis. JAMA Neurol. https://doi.org/10.1001/jamaneurol.2020.2581

31. Sun D, Zhang D, Tian R, et al (2020) The underlying changes and predicting role of peripheral blood inflammatory cells in severe COVID-19 patients: A sentinel? Clin Chim Acta Int J Clin Chem 508:122-129. https://doi.org/10.1016/j.cca.2020.05.027

32. Peng Y, Mentzer AJ, Liu G, et al (2020) Broad and strong memory CD4 + and CD8 + T 
cells induced by SARS-CoV-2 in UK convalescent COVID-19 patients. BioRxiv Prepr Serv Biol. https://doi.org/10.1101/2020.06.05.134551

33. Odak I, Barros-Martins J, Bošnjak B, et al (2020) Reappearance of effector T cells is associated with recovery from COVID-19. EBioMedicine 57:102885. https://doi.org/10.1016/j.ebiom.2020.102885

34. Schwartz MD, Emerson SG, Punt J, Goff WD (2020) Decreased Naïve T-cell Production Leading to Cytokine Storm as Cause of Increased COVID-19 Severity with Comorbidities. Aging Dis 11:742-745. https://doi.org/10.14336/AD.2020.0619

35. Wang B, Wang L, Kong X, et al Long-term coexistence of SARS-CoV-2 with antibody response in COVID-19 patients. J Med Virol n/a: https://doi.org/10.1002/jmv.25946

36. Rajendran K, Krishnasamy N, Rangarajan J, et al (2020) Convalescent plasma transfusion for the treatment of COVID-19: Systematic review. J Med Virol. https://doi.org/10.1002/jmv.25961

37. Li L, Zhang W, Hu Y, et al (2020) Effect of Convalescent Plasma Therapy on Time to Clinical Improvement in Patients With Severe and Life-threatening COVID-19: A Randomized Clinical Trial. JAMA 324:460-470. https://doi.org/10.1001/jama.2020.10044

38. Neutralizing antibody responses to SARS-CoV-2 in a COVID-19 recovered patient cohort and their implications $\mid$ medRxiv. https://www.medrxiv.org/content/10.1101/2020.03.30.20047365v2. Accessed 28 Jun 2020

39. Cho A, Bradley B, Kauffman R, et al (2017) Robust memory responses against influenza vaccination in pemphigus patients previously treated with rituximab. JCI Insight 2:. https://doi.org/10.1172/jci.insight.93222

40. Houot R, Levy R, Cartron G, Armand P (2020) Could anti-CD20 therapy jeopardise the efficacy of a SARS-CoV-2 vaccine? Eur J Cancer 136:4-6. https://doi.org/10.1016/j.ejca.2020.06.017

41. Zohar T, Alter G (2020) Dissecting antibody-mediated protection against SARS-CoV-2. Nat Rev Immunol. https://doi.org/10.1038/s41577-020-0359-5

42. Vabret N, Britton GJ, Gruber C, et al (2020) Immunology of COVID-19: Current State of the Science. Immunity 52:910-941. https://doi.org/10.1016/j.immuni.2020.05.002

43. Liu L, Wei Q, Lin Q, et al (2019) Anti-spike IgG causes severe acute lung injury by skewing macrophage responses during acute SARS-CoV infection. JCI Insight 4:. https://doi.org/10.1172/jci.insight.123158

44. Vardhana SA, Wolchok JD (2020) The many faces of the anti-COVID immune response. J Exp Med 217:. https://doi.org/10.1084/jem.20200678

45. Lucas C, Wong P, Klein J, et al (2020) Longitudinal analyses reveal immunological misfiring in severe COVID-19. Nature. https://doi.org/10.1038/s41586-020-2588-y

46. Maddur MS, Sharma M, Hegde P, et al (2014) Human B cells induce dendritic cell maturation and favour Th2 polarization by inducing OX-40 ligand. Nat Commun 5:4092. https://doi.org/10.1038/ncomms5092

47. Ehrenfeld M, Tincani A, Andreoli L, et al (2020) Covid-19 and autoimmunity. Autoimmun 
Rev 102597. https://doi.org/10.1016/j.autrev.2020.102597

48. Getts DR, Chastain EML, Terry RL, Miller SD (2013) Virus infection, antiviral immunity, and autoimmunity. Immunol Rev 255:197-209. https://doi.org/10.1111/imr.12091

49. Lazarian G, Quinquenel A, Bellal M, et al (2020) Autoimmune haemolytic anaemia associated with COVID-19 infection. Br J Haematol. https://doi.org/10.1111/bjh.16794

\section{TABLES}

\section{Table 1 Summary of PID cases with COVID-19}

XLA-X-linked agammaglobulinemia

ARA- autosomal recessive agammaglobulinemia

CVID-common variable immunodeficiency

SAD- specific antibody deficiency

ALPS-autoimmune lymphoproliferative syndrome

c/c- Chronic

COPD-Chronic obstructive pulmonary disease

HTN-Hypertension

ILD-Interstitial lung disease

ITP-Immune thrombocytopenia

IVIG-Intravenous immunoglobulin

HCQ-Hydroxychloroquine

MMF- Mycophenolate Mofetil

CXR-Chest X ray

GGO-Ground glass opacity

DAT- Direct antiglobulin test 
B/l-Bilateral

BAL- Bronchoalveolar lavage

II-CT of lung

$\S$-Mechanical ventilation unless specified

+- indicates patient was continuing hospitalisation

\section{Table 2 Summary of patients on B cell therapy and COVID-19}

AAV-anti-neutrophil cytoplasmic antibodies (ANCA)-associated vasculitis

GPA -granulomatous polyangiitis

SSc-Systemic sclerosis

RA-Rheumatoid arthritis

RRMS- Relapsing-remitting multiple sclerosis

PPMS-Primary progressive multiple sclerosis

SPMS-Secondary-Progressive Multiple Sclerosis

DLBCL-Diffuse large B cell lymphoma

FL-Follicular lymphoma

MCL-Mantle cell lymphoma

CYC -Cyclophosphamide

TNFi-TNF inhibitor

MMF- Mycophenolate Mofetil

MTX-Methotrexate

Lef-Leflunomide 
Pred-Prednisolone

RTX-Rituximab

IFN $\beta$-1a interferon beta-1a

R-CHOP- Rituximab, Cyclophosphamide, Hydroxydaunomycin, Oncovin and Prednisone

DA-EPOCH-R- Dose-adjusted Etoposide, Prednisone, Vincristine, Cyclophosphamide, Doxorubicin, and Rituximab

R-DeVIC -Rituximab, Dexamethasone, Etoposide, Ifosfamide, Carboplatin

COPD-Chronic obstructive pulmonary disease

HTN-Hypertension

DM-Diabetes Mellitus

ILD-Interstitial lung disease

PAH-Pulmonary Arterial hypertension

CKD-Chronic Kidney Disease

BMI- Body Mass Index

B/l-Bilateral

CXR-Chest X ray

GGO-Ground glass opacity

II -CT of lung

§-Mechanical ventilation unless specified

+- indicates patient was continuing hospitalisation 


\begin{tabular}{|c|c|c|c|c|c|c|c|c|c|c|c|c|c|c|c|c|c|c|c|c|c|c|c|c|c|}
\hline $\begin{array}{l}\text { Patient } \\
\text { Name }\end{array}$ & \begin{tabular}{|l} 
Age(y \\
rs)// \\
Sex
\end{tabular} & \begin{tabular}{|l|} 
\\
\\
Prima \\
ry \\
Diagn \\
osis
\end{tabular} & $\mid \begin{array}{l}\text { Age at } \\
\text { diagn } \\
\text { osis(i } \\
\text { n yrs } \\
\text { unles } \\
\text { s } \\
\text { specif } \\
\text { ied })\end{array}$ & $\begin{array}{l}\text { Treat } \\
\text { ment } \\
\text { for } \\
\text { prima } \\
\text { ry } \\
\text { diagn } \\
\text { osis }\end{array}$ & Comorbidities & $\begin{array}{l}\text { Clinical } \\
\text { features } \\
\text { COVID } 19\end{array}$ & $\begin{array}{l}\text { CRP } \\
\text { in } \\
\text { mg/l }\end{array}$ & \begin{tabular}{|l} 
Ferriti \\
$\mathrm{n}$ in \\
$\mathrm{\mu g} / \mathrm{L}$
\end{tabular} & $\mid \begin{array}{l}\text { CD3 } \\
\text { cell } \\
\text { count } \\
\text { in } \\
\text { mm3 }\end{array}$ & \begin{tabular}{|l} 
CD4 \\
cell \\
count \\
in \\
mm3
\end{tabular} & $\left|\begin{array}{l}\text { CD8c } \\
\text { ell } \\
\text { count } \\
\text { in } \\
\text { mm3 }\end{array}\right|$ & $\begin{array}{l}\text { NK } \\
\text { cell } \\
\text { count } \\
\text { in } \\
\text { mm3 }\end{array}$ & $\begin{array}{l}\text { CD19 cell } \\
\text { count in } \\
\text { mm3 } \\
\text { (Time } \\
\text { between } \\
\text { COVID-19 } \\
\text { diagnosis } \\
\text { and CD19 } \\
\text { estimatio } \\
\text { n) }\end{array}$ & $\begin{array}{l}\mathrm{lgG} \text { in } \\
\mathrm{mg} / \mathrm{dl}\end{array}$ & $\begin{array}{l}\lg A \text { in } \\
\mathrm{mg} / \mathrm{dl}\end{array}$ & $\begin{array}{l}\mathrm{lgM} \text { in } \\
\mathrm{mg} / \mathrm{dl}\end{array}$ & Imaging & $\mid \begin{array}{l}\text { Other } \\
\text { Comp } \\
\text { licatio } \\
\text { ns }\end{array}$ & \begin{tabular}{|l|} 
\\
\\
Oxyge \\
$n$ \\
requir \\
ement
\end{tabular} & \begin{tabular}{|l|} 
Ventil \\
ation§ \\
(Day \\
of \\
ventil \\
ation \\
from \\
onset \\
of \\
disea \\
se)
\end{tabular} & $\begin{array}{l}\text { Treatment } \\
\text { for COVID } 19\end{array}$ & Outcom & \begin{tabular}{|l} 
Days \\
to \\
recov \\
ery/ \\
death \\
from \\
onset \\
of \\
disea \\
se
\end{tabular} & $\begin{array}{l}\text { Course of } \\
\text { Hospital } \\
\text { stay }\end{array}$ & $\begin{array}{l}\text { Autho } \\
\text { rs }\end{array}$ \\
\hline P1 & $34 / \mathrm{M}$ & XLA & $4 \mathrm{mo}$ & IVIG & Nil & $\begin{array}{l}\text { fever, } \\
\text { cough }\end{array}$ & 78 & 469 & 1040 & 495 & 509 & 11.6 & $0(0)$ & 860 & ND & ND & $\begin{array}{l}\text { CXR-Interstitial } \\
\text { pneumonia }\end{array}$ & nil & no & no & \begin{tabular}{|l|} 
IVIG, \\
HCQ,lopinavir \\
/ritonavir
\end{tabular} & $\begin{array}{l}\text { Recovere } \\
\mathrm{d}\end{array}$ & 22 & \begin{tabular}{|l|} 
admitted on \\
d8, \\
recovered \\
on d 22 \\
\end{tabular} & \begin{tabular}{|l} 
Soresi \\
na
\end{tabular} \\
\hline P2 & $26 / \mathrm{M}$ & XLA & 1 & IVIG & Nil & $\begin{array}{l}\text { vomiting,an } \\
\text { orexia }\end{array}$ & 3.6 & 774 & 1791 & 849 & 578 & 5.3 & $0(0)$ & 863 & ND & ND & \begin{tabular}{|l} 
CXR-Interstitial \\
pneumonia
\end{tabular} & nil & no & no & \begin{tabular}{|l} 
VIG, $H C Q$, \\
azithromycin,c \\
eftriaxone
\end{tabular} & $\begin{array}{l}\text { Recovere } \\
\mathrm{d}\end{array}$ & ND & ND & $\begin{array}{l}\text { Soresi } \\
\text { na }\end{array}$ \\
\hline P3 & $34 / \mathrm{M}$ & XLA & 1 & IVIG & Bronchiectasis & high fever & 26 & ND & 1600 & 900 & 700 & 28 & $0(4)$ & 800 & 0 & 0 & \begin{tabular}{|l|} 
CXR-mild \\
interstitial \\
alveolar \\
infiltrates
\end{tabular} & nil & no & no & \begin{tabular}{|l|}
$\mathrm{HCQ}$ \\
ceftriaxone, \\
lopinavir/riton \\
avir
\end{tabular} & $\begin{array}{l}\text { Recovere } \\
d\end{array}$ & 14 & $\begin{array}{l}\text { Admitted on } \\
\text { d6, } \\
\text { recovered } \\
\text { on d14 }\end{array}$ & Quinti \\
\hline P4 & $53 / \mathrm{M}$ & ARA & 18 & IVIG & $\begin{array}{l}\text { Rt upper } \\
\text { lobectomy for } \\
\text { bronchiectasis, } \\
\text { c/c } \\
\text { sinusitis,COPD } \\
\text {, Bronchiectasis }\end{array}$ & $\begin{array}{l}\text { Asymptoma } \\
\text { tic }\end{array}$ & 1 & ND & 1247 & 480 & 739 & 25 & $0(2 \mathrm{mo})$ & 750 & 0 & 0 & \begin{tabular}{|l|} 
Isimilar to pre- \\
covid
\end{tabular} & nil & no & no & \begin{tabular}{|l|}
$\mathrm{HCQ}$, \\
azithromycin, \\
darunavir/cobi \\
cistat
\end{tabular} & $\begin{array}{l}\text { Asympto } \\
\text { matic }\end{array}$ & 0 & & $\begin{array}{l}\text { Quinti } \\
\text { I }\end{array}$ \\
\hline P5 & $59 / F$ & CVID & 48 & IVIG & $\begin{array}{l}\text { c/c sinusitis,c/c } \\
\text { bronchitis }\end{array}$ & $\begin{array}{l}\text { high fever, } \\
\text { dyspnea }\end{array}$ & ND & ND & 1030 & 672 & 338 & 46 & $400(2 \mathrm{mo})$ & 897 & 30 & 33 & ND & ND & yes & yes & $\begin{array}{l}\text { Tocilizumab, } \\
\mathrm{HCQ}, \\
\text { azithromycin }\end{array}$ & Died & 17 & ND & $\begin{array}{l}\text { Quinti } \\
1\end{array}$ \\
\hline P6 & $32 / \mathrm{F}$ & CVID & 14 & Nil & Melanoma & $\begin{array}{l}\text { high fever, } \\
\text { cough,dysp } \\
\text { nea }\end{array}$ & 7.5 & 4000 & 1800 & 950 & 850 & 30 & $200(2 \mathrm{mo})$ & 500 & 0 & 153 & $\begin{array}{l}\text { IInterstitial } \\
\text { pneumonia }\end{array}$ & nil & yes & no & $\begin{array}{l}\text { Tocilizumab(2 } \\
\text { ), } \mathrm{HCQ}, \\
\text { darunavir/riton } \\
\text { avir }\end{array}$ & $\begin{array}{l}\text { Recovere } \\
\text { d }\end{array}$ & $17+$ & $\begin{array}{l}\text { Admitted on } \\
\text { d13, } \\
\text { improved on } \\
\text { d17 }\end{array}$ & $\begin{array}{l}\text { Quinti } \\
1\end{array}$ \\
\hline P7 & $57 / \mathrm{M}$ & CVID & 49 & IVIG & $\begin{array}{l}\text { Asthma,HTN,o } \\
\text { besity }\end{array}$ & $\begin{array}{l}\text { high fever, } \\
\text { cough,dysp } \\
\text { nea }\end{array}$ & 1200 & ND & 3200 & 2767 & 1653 & 21 & $96(4 \mathrm{mo})$ & 550 & 40 & 44 & $\mid \begin{array}{l}\text { CXR-interstitial } \\
\text { pneumonia, } \\
\text { alveolar } \\
\text { consolidation }\end{array}$ & \begin{tabular}{|l|} 
Candi \\
da on \\
BAL
\end{tabular} & yes & yes (d9 & \begin{tabular}{|l|} 
lopinavir/riton \\
avir, \\
remdesivir \\
methylprednis \\
olone
\end{tabular} & $\begin{array}{l}\text { Recovere } \\
d\end{array}$ & 34 & $\begin{array}{l}\text { Admitted on } \\
\text { d5, recovere } \\
\text { d on d35 }\end{array}$ & $\begin{array}{l}\text { Quinti } \\
1\end{array}$ \\
\hline P8 & $52 / \mathrm{M}$ & CVID & 24 & IVIG & $\begin{array}{l}\text { ITP, } \\
\text { lymphoprolifera } \\
\text { tion, ILD }\end{array}$ & $\begin{array}{l}\text { high fever, } \\
\text { dyspnea }\end{array}$ & ND & ND & 750 & 274 & 258 & 85 & $55(3 \mathrm{mo})$ & 662 & 11 & 8 & $\begin{array}{l}\text { TInterstitial } \\
\text { pneumonia }\end{array}$ & nil & no & no & \begin{tabular}{|l|}
$\mathrm{HCQ}$, \\
azithromycin, \\
lopinavir/riton \\
avir
\end{tabular} & $\begin{array}{l}\text { Recovere } \\
d\end{array}$ & 11 & $\begin{array}{l}\text { Admitted on } \\
\text { d6, } \\
\text { recovered } \\
\text { on d11 }\end{array}$ & $\begin{array}{l} \\
\text { Quinti } \\
\end{array}$ \\
\hline P9 & $41 / \mathrm{M}$ & CVID & 14 & IVIG & c/c sinusitis & $\begin{array}{l}\text { high fever, } \\
\text { cough,dysp } \\
\text { nea }\end{array}$ & 315 & 7200 & 1500 & 800 & 700 & 15 & $278(6 \mathrm{mo})$ & 700 & 10 & 30 & $\begin{array}{l}\text { TInterstitial } \\
\text { pneumonia }\end{array}$ & nil & yes & \begin{tabular}{|l|} 
yes (d8 \\
\end{tabular} & $\begin{array}{l}\text { Tocilizumab(1 } \\
\text { ), HCQ, } \\
\text { piperacillin/taz } \\
\text { obactam, } \\
\text { lopinavir/riton } \\
\text { avir, } \\
\text { remdesivir }\end{array}$ & $\begin{array}{l}\text { Recovere } \\
\mathrm{d}\end{array}$ & $13+$ & $\begin{array}{l}\text { Admitted on } \\
\text { d8, } \\
\text { improved on } \\
\text { d13 }\end{array}$ & $\begin{array}{l} \\
\text { Quinti } \\
\text { I }\end{array}$ \\
\hline
\end{tabular}




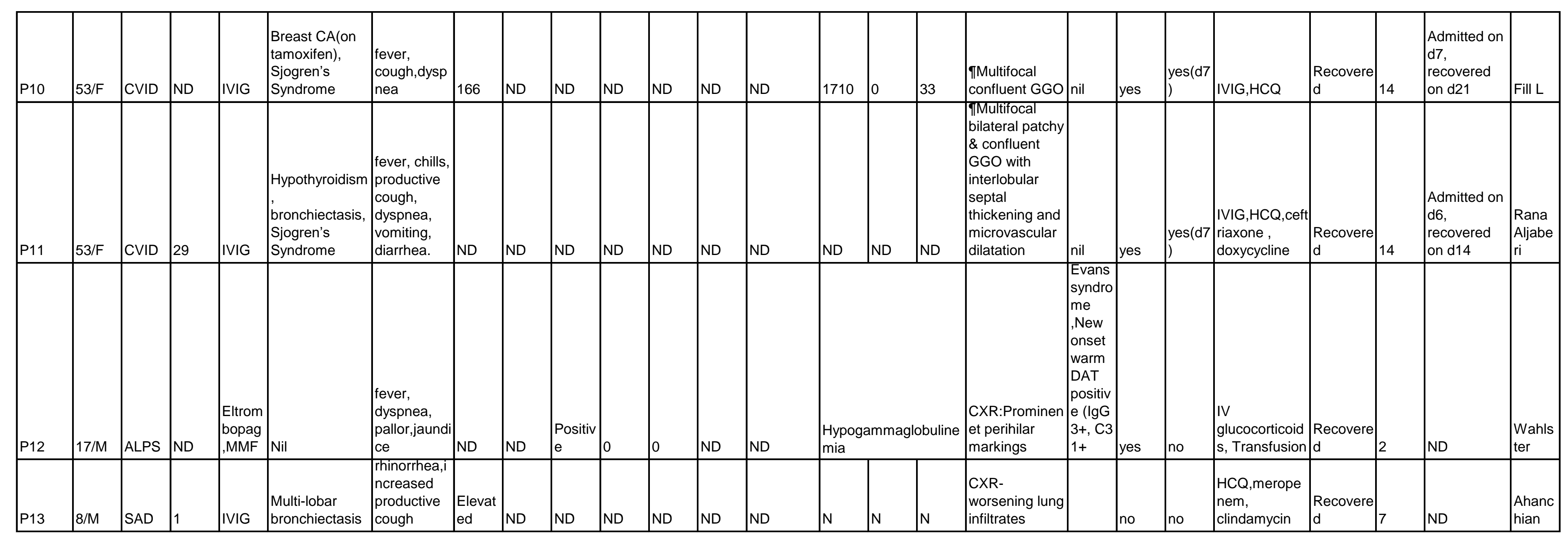




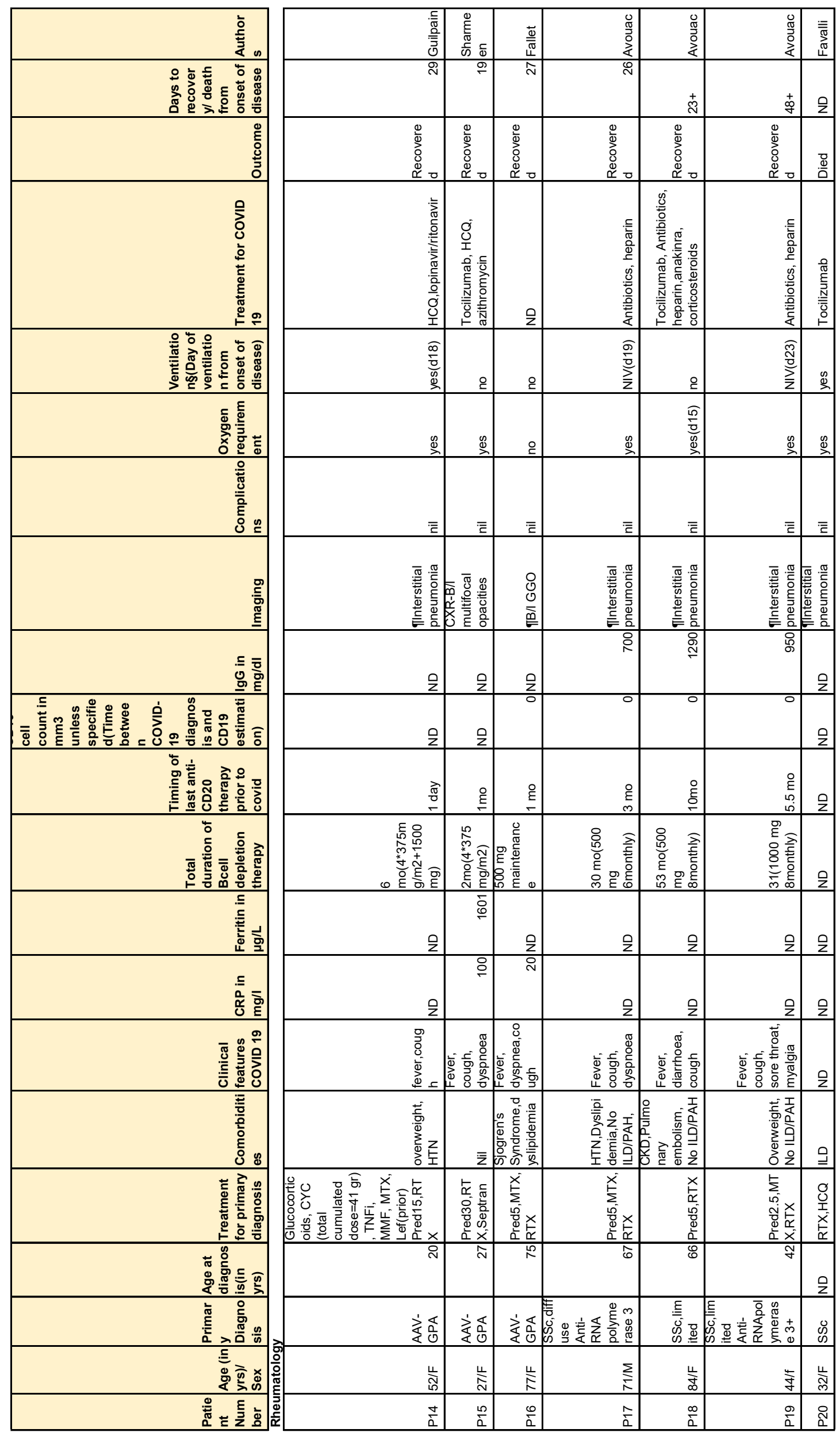




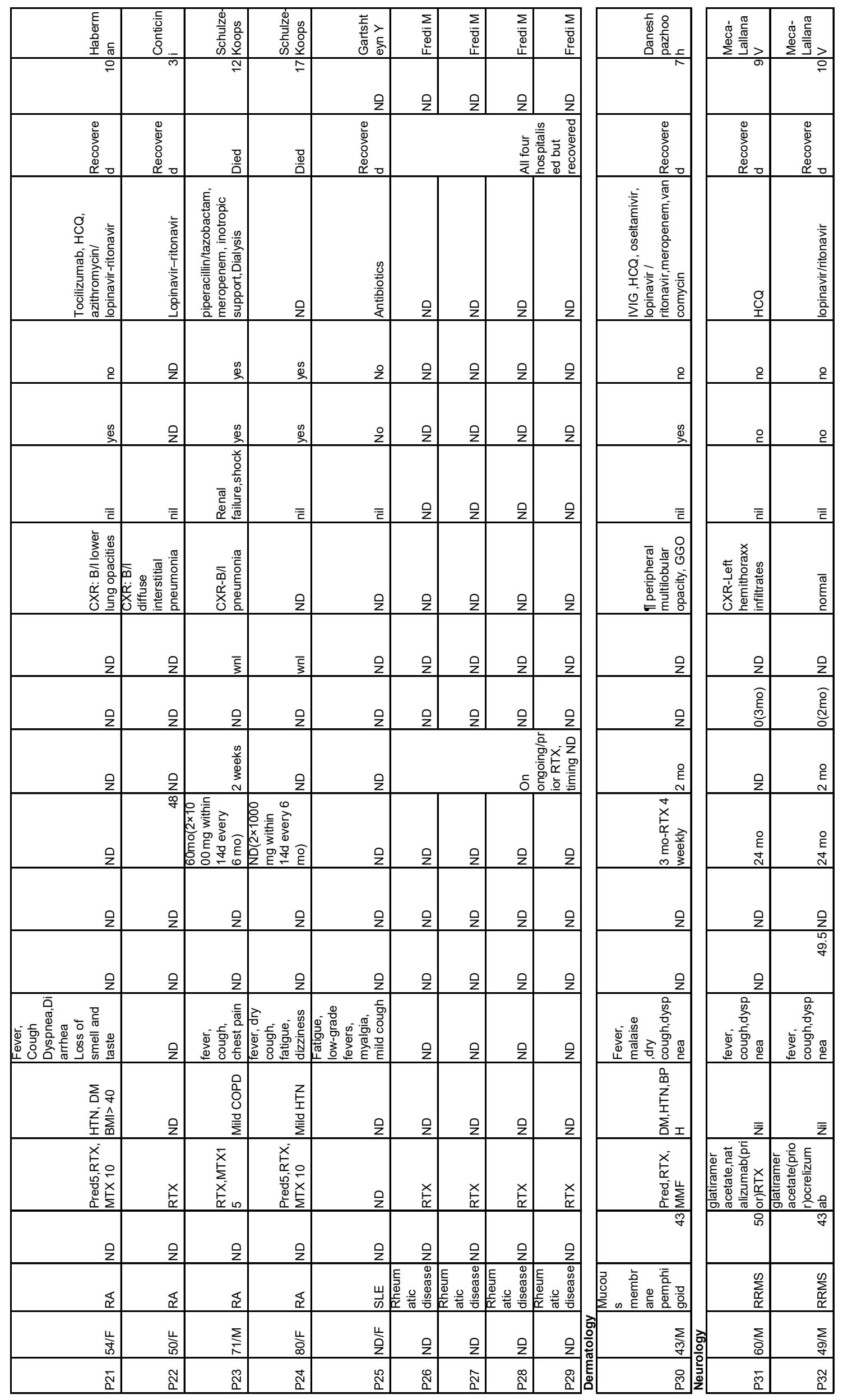




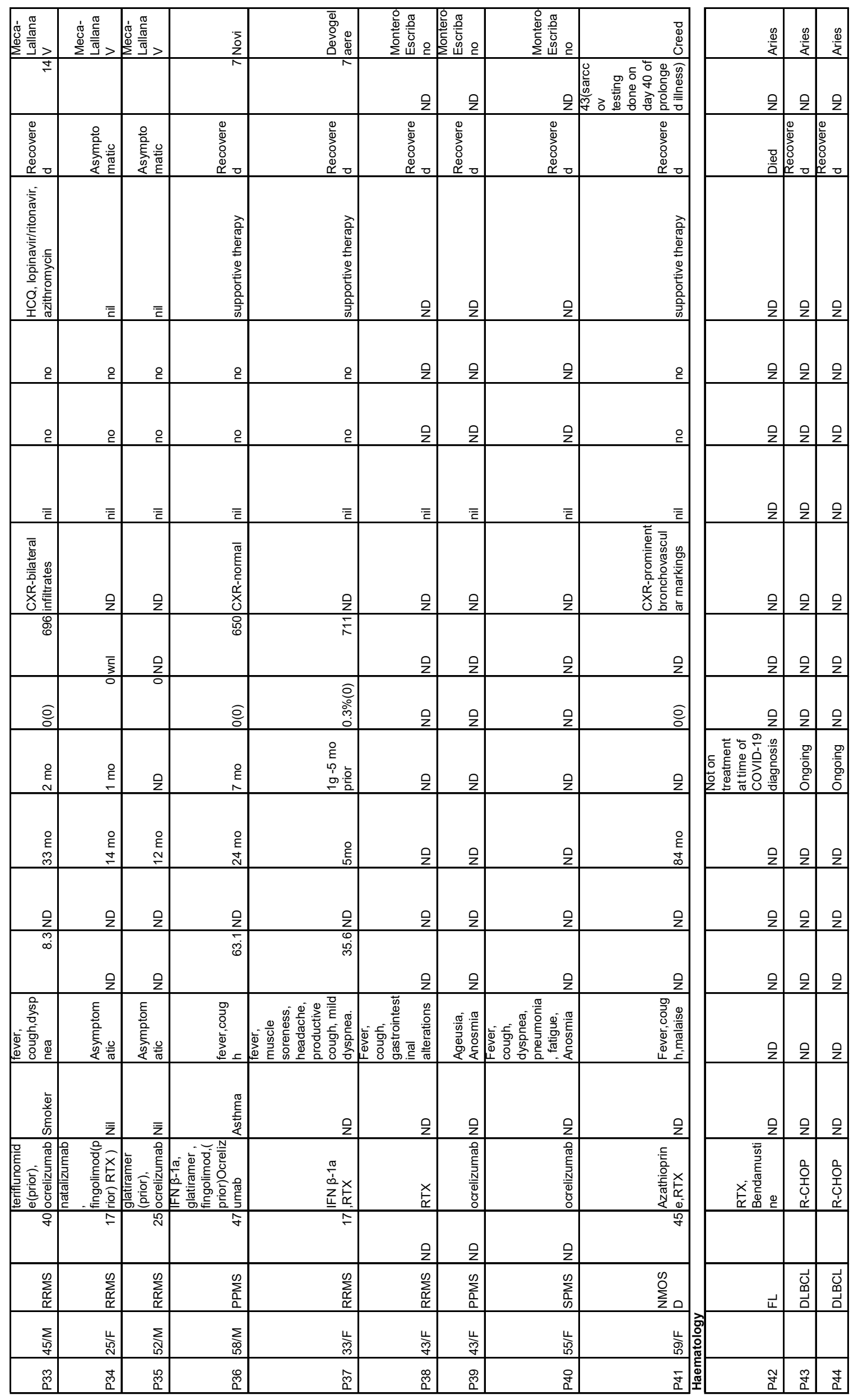




\begin{tabular}{|c|c|c|c|c|c|c|c|}
\hline 畩 & 造 & 畩 & 尊 & 畩 & ב & 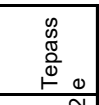 & 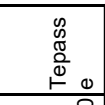 \\
\hline$\frac{1}{2}$ & $\frac{a}{z}$ & $\frac{\rho}{2}$ & $\frac{1}{2}$ & $\frac{1}{2}$ & & & \\
\hline - & 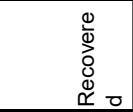 & 竞 & 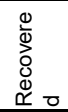 & 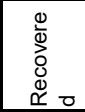 & 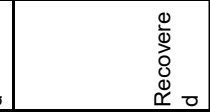 & 踫 & 兽 \\
\hline$\frac{2}{2}$ & $\frac{q}{2}$ & 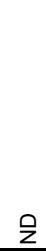 & $\frac{q}{2}$ & $\frac{2}{2}$ & 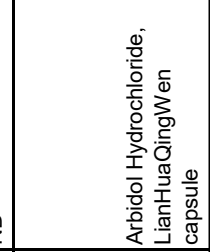 & 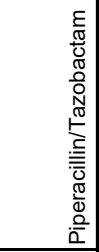 & 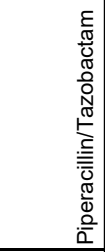 \\
\hline 之 & $\frac{\eta}{2}$ & $\frac{\rho}{2}$ & $\frac{1}{2}$ & $\frac{1}{2}$ & \& & 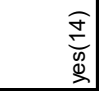 & 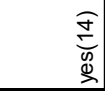 \\
\hline$\frac{2}{2}$ & $\frac{\eta}{2}$ & $\frac{\rho}{2}$ & $\frac{\rho}{2}$ & $\frac{2}{2}$ & $\frac{\rho}{2}$ & $\stackrel{D}{2}$ & $\stackrel{\infty}{2}$ \\
\hline 之 & $\mathrm{z}$ & $\frac{\rho}{z}$ & $\frac{\rho}{z}$ & $\mathrm{Q}$ & 之 & 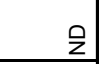 & 吕 \\
\hline z & $\frac{q}{z}$ & $\frac{q}{z}$ & $\frac{1}{z}$ & & 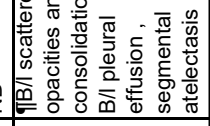 & 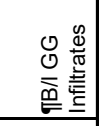 & 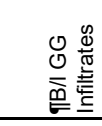 \\
\hline z & $\mathrm{z}$ & 之 & $\frac{1}{2}$ & $\frac{1}{2}$ & $\frac{\eta}{z}$ & $\underline{z}$ & $\underline{z}$ \\
\hline 之 & 之 & 之 & ₹ & $\frac{\eta}{z}$ & 之 & & \\
\hline 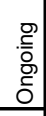 & 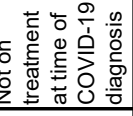 & $\begin{array}{l}\text {. } \\
\text { के } \\
\text { ठ } \\
\end{array}$ & 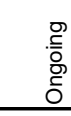 & $\begin{array}{l}\text { ग्र } \\
\text { के } \\
\text { ठ } \\
\end{array}$ & 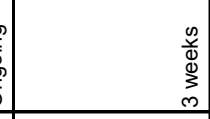 & 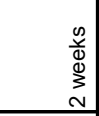 & 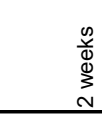 \\
\hline z & $\mathrm{z}$ & 之 & 之 & $\frac{\eta}{z}$ & 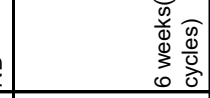 & 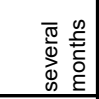 & 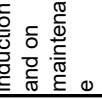 \\
\hline 之 & 之 & 之 & ₹ & $\frac{\eta}{z}$ & $\frac{\eta}{z}$ & & i \\
\hline z & $\mathrm{Q}$ & z & 号 & $\frac{\eta}{z}$ & 之 & & \\
\hline z & $\mathrm{z}$ & z & 之 & $\frac{\rho}{2}$ & 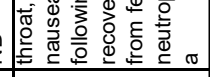 & $\frac{\eta}{z}$ & ₹ \\
\hline 之 & z & 之 & 之 & z & 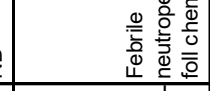 & 罕 & $\frac{P}{U}$ \\
\hline $\begin{array}{l}0 \\
\text { ơ } \\
\text { ơ } \\
\text { 主 } \\
\end{array}$ & 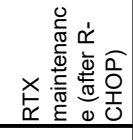 & 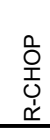 & 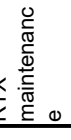 & 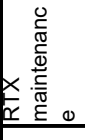 & 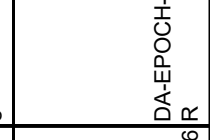 & 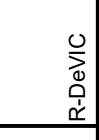 & 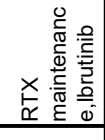 \\
\hline $\begin{array}{l}\vec{D} \\
\stackrel{्}{\Delta} \\
\end{array}$ & 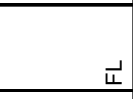 & $\begin{array}{l}\overrightarrow{0} \\
\stackrel{्}{\Delta} \\
\end{array}$ & $\frac{\overrightarrow{0}}{\Sigma}$ & $\overrightarrow{\underline{u}}$ & 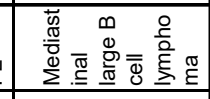 & 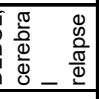 & $\stackrel{\overrightarrow{0}}{\Sigma}$ \\
\hline & & & & & $\sum_{\substack{\infty \\
N}}$ & $\sum_{\substack{0 \\
0}}$ & $\sum_{0}^{0}$ \\
\hline$\frac{q}{2}$ & $\begin{array}{l}0 \\
0 \\
0 \\
0\end{array}$ & 证 & 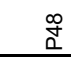 & $\frac{g}{Q}$ & $\begin{array}{l}\circ \\
\text { 员 } \\
0 .\end{array}$ & $\bar{i}$ & ్ㅜㅇ \\
\hline
\end{tabular}

